\title{
Nitrogen solubility index and amino acid profile of extruded African breadfruit (T. africana) blends
}

\author{
Nwabueze, T. U. \\ Department of Food Science and Technology, Michael \\ Okpara University of Agriculture, Umudike, \\ P.M.B. 7267, Umuahia, Abia State, Nigeria. \\ E-mail:teeubueze@yahoo.co.uk
}

ABSTRACT

\begin{abstract}
Flours from African breadfruit, corn and defatted soybean were thoroughly mixed in a Hobart_-mixer at three variable, with the following combinations 40:5:55, 55:5:40, 70:5:25, 85:5:10 and 100:0:0\% for African breadfruit, corn and soybean, respectively. These combinations were hydrated to moisture contents of 15 , $18,21,24$, and $27 \%$ and extruded at screw speed of 100 , 120, 140, 160 and ISOrpm in a Brabender laboratory single-screw extruder. Effects of extrusion cooking and process variable conditions on nitrogen solubility index and amino acid profile were investigated. Nitrogen solubility index decreased with extrusion cooking by more than $50 \%$ in all the point blends. Soybean lowered nitrogen solubility index while African breadfruit increased it from
\end{abstract}

17 to $22 \%$ in the raw and 7.25 to $9 \%$ in the extruded samples. The model developed in the study accounted for $60.21 \%$ of the total variation in nitrogen solubility index and significantly $(\mathrm{p}<0.05)$ fitted. Feed moisture had significant $(\mathrm{p}<0.05)$ linear effect on nitrogen solubility index and a significant $(\mathrm{p}<0.05)$ cross product effect on interaction with screw speed. Retention of amino acid originally present in the raw was high ranging from 79 to $84 \%$, indicating that process variable conditions were adequate and that blending African breadfruit with corn and defatted soybean before extrusion cooking has great nutritional benefit.

Keywords: African breadfruit; (T. africana); amino acids; extrusion, nitrogen solubility index

\section{INTRODUCTION}

$\mathrm{T}$ The practice of blending locally grown crops in Nigeria partly for aesthetic purposes and partly as nutrient supplementation has been an age long tradition. African breadfruit (Treculia africana) produced in the Southern parts of Nigeria during the hungry season (March-July) of the year, sustains the population following cultivation of major staples such as rice, corn, yam, and cassava, as main dish or snack food. The fruit head of the crop contains numerous edible seeds embedded in the fleshy pulp of the fruit. The potentials of African breadfruit as a nutrient resource and its position in the food cycle of the people makes it's blending with other local ingredients one important way of expanding the scope of its utilization. Consumption of blends of dehulled whole seeds of the African breadfruit and shelled milk-corn is popular even beyond the producing communities in Nigeria. Ariahu et al. (1999) reported blending soybean and African breadfruit seeds for formulation of acceptable weaning diet. Most of these blending and their processes have not been experimentally optimized for maximizing products in mind.

Extrusion technology is one of the most versatile and well-established processes used in the food industry today. Its application in Nigeria has been reported for soybean flour and its blends with other cereals and low protein legume (Dashiell et al., 1990; Lasekan and Akintola, 2002; Iwe et al., 2004). There is generally a dearth of information on the extrusion of African breadfruit and or its blends with corn and soybean, which makes it a preferred technology 
in this study. Although physical techniques are being employed in industry as well as in academia to measure various quality attributes in extruded products, comparison of data is difficult and relationships between processing variables could not be obtained with out examining a large number of parameter combinations (Richburg and Whittaker, 1990). The solution lies with the application of response surface methodology, which economizes experimental points by compressing them to far less experimental data. It relates product properties to process variables and then describes the interactions between them to give response changes magnitude and direction. The objective of this research is to investigate the effects of extrusion cooking and process variables on nitrogen solubility index and amino acid profile of raw and extruded blends of African breadfruit, corn and defatted soybean.

\section{MATERIALS AND METHODS Raw materials}

About $100 \mathrm{~kg}$ of African breadfruit ( $T$. africana) seeds, $20 \mathrm{~kg}$ of yellow corn and $4 \mathrm{~kg}$ of soybean were used.

\section{Raw materials preparation}

All the raw materials were cleaned in a Vegvari Ferenc aspirator (OB 125 Budapest, Hungry). African breadfruit seeds were hot-water blanched at $100^{\circ} \mathrm{C}$ for $15 \mathrm{~min}$, drained through a plastic basket for $15 \mathrm{~min}$ and cracked in a commercial attrition mill. Dehulled seeds were dried to a moisture content of 5.20-6.20\% in a Chirana - type air convection oven (HS 201 A) at $60^{\circ} \mathrm{C}$. They were milled directly in a Brabender roller mill (made in Germany) to pass through a 75 um sieve openings integral to the mill. Resulting fine flour was stored in airtight container until needed. The yellow corn was first pulverized in a Brook Crompton laboratory hammer mill (DN 158 QW, England) to pass through a $2 \mathrm{~mm}$ sieve.
The coarse flour was later milled in the Brabender roller mill and the flour packaged for later use.

The soybeans were first coarsely milled in the hammer mill and later finished up in the Brabender roller mill. The fine flour was defatted with hexane to $12.20 \%$ final fat content from its original $17.50 \%$. The recovered flour was further milled in the hammer mill to break the flour clumps and then stored until needed.

\section{Pre-extrusion treatment of flours}

Feed composition $\left(\mathrm{x}_{1}\right)$ of flours from African breadfruit, corn and defatted soybean was obtained at the following combinations (40:5:55, 55:5:40, 70:5:25, 85:5:10 and 100:0:0\%, respectively) pre-determined by the experimental design. The feed composition was hydrated by addition of calculated volumes of distilled water (Nwabueze, 2006) to corresponding feed moisture $\left(\mathrm{X}_{2}\right)$ content of 15, 18, 21, 24 and 27\%, according to the design (Table 1). The hydrated feed combinations were thoroughly mixed in a Hobart mixer (A 200, England). Each feed composition $\left(\mathrm{x}_{1}\right)$ with corresponding feed moisture $\left(\mathrm{x}_{2}\right)$ was then divided into three, giving 15 blends (three variables, five level combinations).

\section{Extrusion cooking}

The 15 blends were extruded at screw speed $\left(\mathrm{x}_{3}\right)$ of 100, 120, 140, 160 and 180rpm with the center point blend $\left(70 \mathrm{x}_{1}: 21 \mathrm{x}_{2}: 140 \mathrm{x}_{3}\right)$ replicated ten times to give a total of 25 experimental runs. The extruder has grooved barrel length to diameter $(L / D)$ ratio of 20:1 with variable speed of 0-200rpm. A 4:1 compression ratio screw was employed. The die nozzle diameter and length were 2.2 and $40 \mathrm{~mm}$, respectively. Temperature settings were adjusted using the thermostat such that feeding, compression, metering and die zone temperatures were $120,150,170$, and $150^{\circ} \mathrm{C}$, respectively. 


\section{Preparation of extrudates for analysis}

The extrudates were dried in the oven at 60 ${ }^{0} \mathrm{C}$ to $5-6 \%$ moisture and milled into fine flour in the roller mill. Raw and extruded blends from process variable conditions at higher star$\left(100 \mathrm{x}_{1}: 27 \mathrm{x}_{2:} 180 \mathrm{x}_{3}\right)$, centre- $\left(70 \mathrm{x}_{1}: 21 \mathrm{x}_{2}: 140 \mathrm{x}_{3}\right)$ and lower corner- $\left(40 \mathrm{x}_{1}: 15 \mathrm{x}_{2}: 100 \mathrm{x}_{3}\right)$ points representing higher, intermediate and lower levels of blending were selected from the runs and analyzed for amino acid composition.

\section{Proximate analysis}

Proximate composition of seeds, raw and extruded blends were determined in triplicates for crude protein (Kjeldhal method), fat (soxhlet method), crude fiber and ash according to AOAC (1995). Energy was calculated using the Atwater factors of 4 protein, 4 carbohydrate and 9 fat.

Nitrogen solubility index (NSI)

Nitrogen solubility index (NSI) was determined according to AACC approved method no. 46-23 (AACC, 1983).

\section{Amino acid analysis}

Amino acid profile of raw and extruded samples was done in the Department of Biochemistry, University of Jos, Nigeria. The determination which was in duplicate followed the methods described by previous researchers (Spackman et al, 1958; Benitez, 1989). Amino acids were quantitatively determined against the standard in a Technicon auto analyzer chart (no. Oil- 9648 -01, Technicon Instruments Co., Tarrytown, New York).

\section{Experimental design and statistical analysis}

A central composite rotatable response surface design for a three-variable, five level combinations coded $-1,-1.682,0,+1,+1.682$ (Table 1) as modeled and used in literature (Snedecor and Cochran, 1980; Nwabueze and Iwe, 2006) was adopted (Eq. 1 .) Data on effects of extrusion cooking and process variables on nitrogen solubility index of extruded blends were determined and statistically regressed using
Stagraphic computer software (Statistica). ThreeDimensional response surface plots were made with the same software.

$$
\begin{aligned}
& -\mathrm{Y}=\mathrm{B}_{\mathrm{o}}+\sum \mathrm{B}_{\mathrm{i}} \mathrm{X}_{\mathrm{i}}^{\mathrm{k}}+\sum \mathrm{B}_{\mathrm{ii}} \mathrm{X}_{\mathrm{i}}^{2}+\Sigma \Sigma \mathrm{B}_{\mathrm{ij}}^{\mathrm{k}} \mathrm{X}^{\mathrm{k}} \mathrm{X}_{\mathrm{j}}+\mathrm{E} \\
& \text { (1) } \\
& \mathrm{i}=1 \quad \mathrm{i}=1 \quad \mathrm{i}=1 \quad \mathrm{j}=1 \\
& \mathrm{i}<\mathrm{j}
\end{aligned}
$$

Where $\mathrm{Y}$ is the dependent variable, $\mathrm{X}_{\mathrm{i}}$ and $X_{j}$ the independent variables in the model, $k$ the number of independent variables, $B_{0}$ the intercept (constants and regression coefficients of the model), and e the random error term.

\section{RESULTS AND DISCUSSION}

The proximate composition of African breadfruit, yellow corn and defatted soybean used as raw materials is shown in Table 2. There was significant $(\mathrm{p}<0.05)$ difference in protein, fat and energy composition of the seed materials. Protein content of defatted soybean was 4.9 and 3.0 times more than those for corn and breadfruit, respectively, while the carbohydrate was 2.4 and 2.0 times lower. This has some nutritional benefits and justifies the blending of African breadfruit with soybean and corn in this formulation. African breadfruit is nutritious and a delicacy when cooked with ingredients such as fish and eaten in form of porridge or as substitute to a more expensive rice during festivals.

Nitrogen solubility index is an important product quality generally reflecting the degree of heat treatment received by the product. It could be used as an indicator of degree of cooking and protein digestibility (Molina et al., 1983), which in this study reduced, by $\sim 50 \%$ in each level combination due to extrusion cooking. The decrease shows how much of the protein in the raw blends, denatured by extrusion cooking and suggests a higher protein digestibility. 
The decrease towards lower corner point blending from 22 to $9 \%$ (higher star point blend); 20 to $7.50 \%$ (centre point blend) and 17 to $7.25 \%$ (lower corner point blend) (Table 3) suggests that decrease in carbohydrate (breadfruit) or increase in protein (soybean) source in a food system impairs nitrogen solubility index. Extrusion cooking temperature $\left(120-170^{\circ} \mathrm{C}\right)$ condition in the extruder barrel could have altered the protein moieties.

lowering their ability to solubilize in water. Similar observations have been reported for extruded corn-soy blends (Maga and Lorenz, 1978), navy bean-defatted soy blends (Aguilera and Lusas, 1986) and extrudates of High Starch Fractions (Gujska and Khan, 1990).

Estimated regression coefficients and analysis of variance on effect of process variable conditions of feed composition, feed moisture and screw speed on nitrogen solubility index are presented in Table 4. It shows that feed moisture had a significant $(\mathrm{p}<0.05)$ linear effect on the response (Fig.1). There was also a cross product effect between feed moisture and screw speed, which was significant while the interaction between feed composition and screw speed, was nearly quadratic (Fig.2). In this interaction, NSI reduced to 10,8 and $6.75 \%$ (higher star-, centerand lower corner- point blends, respectively). The analysis of variance confirmed the significant $(p<0.05)$ effects of feed moisture and screw speed on NSI.

The implication of this is that at lower screw speed, residence time (RT) is increased and the dough suffers higher thermal effect given the temperature condition in the extruder barrel. Under these process conditions, the dough becomes more viscous and flow rate is reduced. This effect was more pronounced at lower corner point where process variable conditions were minimum (Table 1). This suggests that NSI is not entirely a function of the extrusion temperature but also that of interaction between components. The model developed for this study contributed about $60.21 \%$ of the total variation in NSI and significantly $(\mathrm{p}<0.05)$ fitted. On removing the non-significant terms and recomputing, the polynomial becomes:

$$
\begin{array}{lrr}
-\mathrm{NSI} & =55.73162 & -0.51299 \mathrm{x}_{2} \\
+0.01948 \mathrm{x}_{2 *} \mathrm{x}_{3} & (2)
\end{array}
$$

Table 5 shows the amino acid composition of raw and extruded African breadfruit at higher star- and other point blends. In the higher star point blend, the glutamic acid had the highest value $(9.65 \mathrm{~g} / 16 \mathrm{gN})$ followed by leucine $(5.25 \mathrm{~g} /$ $16 \mathrm{gN})$ while cystine was the least $(1.20 \mathrm{~g} / 16 \mathrm{gN})$ followed by methionine $(1.40 \mathrm{~g} / 16 \mathrm{gN})$ and others. The deficiency of some amino acids particularly methionine and cystine in African breadfruit seed calls for both complementary and supplementary blending with animal, cereal or other legume proteins. Traditionally, dehulled African breadfruit seeds and shelled milk-corn are popularly consumed in the Southern parts of Nigeria particularly during the early seasons of corn production. It is expected that corn will contribute its sulfur containing amino acids deficient in breadfruit protein while soybean supplements with its high amount of lysine (Iwe et al., 2001). The use of animal protein sources such as crayfish, periwinkle and snails (Umoh and Bassir, 1977), and soybean (Ariahu et al, 1999) to supplement African breadfruit meals have been reported in literature for similar reasons. Addition of corn and defatted soy in the blend generally increased most amino acids low in higher star point blend. Aspartic acid increased by 24 to $46 \%$, histidine by 23 to $25 \%$, lysine by 14 to $90 \%$, leucine by 19 to $33 \%$, phenylalanine by 12 to $14 \%$, proline by 15 to $25 \%$, tyrosine by 2 to $18 \%$ and methionine by $17 \%$ while cystine and serine increased by more than $100 \%$ when soybean increased from $25 \%$ in the center point blend to $55 \%$ in the lower corner point blend. 
This obviously indicates a significant improvement in the nutritional values of African breadfruit with blending with defatted soybean and corn.

Extrusion cooking generally reduced the aini.no acid content of the extruded blends (Table 5). However, it is interesting to note that all the extruded samples met the amino acid requirement patterns for human adults (RDA, 1989; Sotillo and Hettiarachchy, 1994): lysine, 1.6; threonine, 2.8; valine, 2.5; methionine, 1.0; isoleucine, 1.3; leucine, 1.9 and phenylalanine + tyrosine, $1.9 \mathrm{~g}$ amino acid $/ 100 \mathrm{~g}$ protein. Apart from lysine, all the extrudates particularly those from blends containing higher concentrations of defatted soy (lower corner point) met the amino acid requirement patterns for children between 2 - 10years (FAO/WHO, 1973): lysine, 4.4; histidine, 1.9; threonine, 2.8; cystine, 1.2; valine, 2.5; methionine, 1.3 ; isoleucine, 2.8 ; leucine, 4.4 ; tyrosine, 1.1 and phenylalanine, $1.0 \mathrm{~g}$ amino acid/ $100 \mathrm{~g}$ protein. Table 6 shows the percent loss or gain in amino acid composition due to extrusion cooking. Lower losses indicated higher aiiiino acid retention in the extrudates. Total inline acid retention in the extruded blends in this study averaged $80 \%$ of that in the raw blends. Some of the high amino acid losses observed in the higher star point drastically reduced with blending at centre- and lower comer points. Losses in arginine reduced from 16.62 to $3.59 \%$, glutamic acid from 24.87 to $5.39 \%$, isoleucine from 45.12 to $0.93 \%$ and tyrosine from 35.09 to $10.16 \%$ as defatted soybean addition increased from $0 \%$ at higher star point to $55 \%$ in the lower corner blends. Losses in lysine ranged from $31.82 \%$ at higher star point to a maximum of $36.11 \%$ at rhe lower corner point. Lysine has been reported (Iwe el al.,'2001) to serve as indicator of protein damage during processing which at more intense extrusion cooking conditions, may be reduced through the Miliard reaction.
Higher losses in lysine, methionine and cystein with heat processes (toasting or frying) other than by extrusion processing have been reported for chickpea and its biscuit, (Camovale et al., 1987).

\section{CONCLUSION}

Extrusion cooking reduced NSI by more than $50 \%$ in all the point blends. Feed moisture had sirjnirtw'nt $(\mathrm{p}<0.05)$ linear effect on NSI while an .interaction effect between feed moisture anc screw speed was significant. Higher NSI was obtained at minimum screvv speed and 'bed moisture for each variable level.Feed composition influenced amino acid profile of the samples with increasing effect as defatted soybean was increased. Although extrusion cooking reduced the amino acid composition of the blends, an average of $80 \%$ of the amino acids originally present in the blends was retained'in the extruded'samples. It could be stated therefore that blending African breadfruit. with other food sources has great nutritious benefit in terms of protein enhancement and amiho acid retention in the extruded 'samples.

\section{REFERENCES}

AACC (1983). Approved methods of AACC, Method $30-25,8^{\text {th }}$ ed. Amer. Assoc. Cereal Chem, St. Paul, MN.

Aguilera, J. M. and Lusas, E. W. (1986). Laboratory and pilot extraction of extruded highoil corn. J_-Amer. oil Chem. Sod. 63: 239-243.

AOAC (1995). Official Methods of Analysis. (15 $5^{\text {th }}$ ed.) Association of Official Analytical Chemists. Arlington, VA: Association of Analytical Chemists. Ariahu, C. C., Ukpabi, U. and Mbajunwa. K. O. (1999). 
Production of African breadfruit (Treculiaqfricana) and soybean (Glycine max) seed based food formulations, 1 : seed based food formulations, 1: Effects of germination and fermentation on nutritional and organoleptic quality. Plant Foods Hum. Nutr. 54: 193 -206.

Benitez, L. V. (1989). Amino acid and fatty acid profiles in aquaculture nutrition studies. In: Fish Nutrition Research in Asia. Proceedings of The Third Asian Fish, SS Die Silva (ed.). Soc. Spec.Publ. 4: I66p. Asian Fisheries Society. Manila, Philippines, p 23 - 35.

Camovale, E., Cappelloni, M., Mosconi, C.,Marietta, L. and Pollini, C. (1987). Effect of extrusion cooking on protein availability and sulphur amino acids of faba bean and Chickpea products. Proceedings of the $7^{\text {th }}$ World Congress Food Science and Technology. Trends in Food Processing 1: Membrane Filtration Technclogy and Thermal Processing and Quality of Foods. Singapore. October. AH Ghee et al. (Eds.). 241 246.

Dashieil, K. E., Singh, S. R., Nakayama, O., Ogunciipe, H. O. and Alcem, C. N. (1990). Clip a research monograph no. 2, Soyabsan Research at IITA. Ibadan, Nigeria.

FAO/WHO (3973). Energy and proteinrequirements. Reports of joint $\mathrm{F}$ A O / WHO ad hoc Expert Committee. Rome.

Gujska, E. and Khan, K. (1990). Effect of temperature on properties of extrudat.es frem high starch fraction of navy, pinto and garbanzo beans. J. Food Sci. 55, 466 - 469.

Iwe, O'.. van Zuilichem, D. J., Ngoddy, f. O: and Lammers, W. (2001). Amino ac'd and protein dispcrsibility index (FDI) of mixuurs of exl.ri.Kted ' soy and svy'eei potato flours:
Lebensmlttel - Wisscnschft Und - Techonologie 34:71-75.

Iwe, M. O., van Zuilichem. D. J.. Stolp. W. and Ngoddy, P. O. (2004). Effect of extrusion ' cocking of soy-sweet potato mixtures on I available lysine content and browning index of extrudates. J. Food Engr. 62:143-150.

Lasekan, O. O. and Akimola, A. M.” ',2002). Production and nutritional evaluation of puffed soy-maize snack. Nig. Food J. 20: 15 -19.

Maga, J. A. and Lorenz, K. (1978). Sensory and Physical properties of extruded corn-soy blends. Lebensmittel - Wissenschaft und-Technologie 11:2185.

Molina, M. R., Braham, J. E. and Bressani, R. (1983). Some characteristics of whole corn: whole soybean (70:30) and rice: whole soybean (70:30) mixtures processed by simple extrusion cooking. J. Food Sci. 48: 434 - 437.

Nwabueze, T. U. (2006). Effect of hydration and screw speed on the nutrient and acceptability of extruded ready-to-eat African breadfruit (Treculia africana) snack. Nigerian Food Journal, 24(1): 107-112.

Nwabueze, T. U. and Iwe, M O. (2006). Mass flow rate, nutrient composition and some functional properties of single screw extruded African breadfruit (Treculia africana) blends. Journal of Food Technology, 4 (1): 50-58.

RDA (1989). Recommended Dietary Allowance, $10^{\text {th }}$ ed. National Research Council, National Academy Press.

Richburg, I. L. and Whittaker, A. D. (1990). Response surface characterization of a twin- 
screw -extruder. In: Engineering and Food. Advanced Processes. Spiess, W.E.L. and Schubert, H., eds.,

Elsevier Applied Science: London and New York. pp. 332 - 340. Snedeeor,_G. W. and Cochran^W. (1980). Statistical Methods, ( $7^{\text {the }}$ edn), Iowa State University Press, Ames, IA p 215.

Sotillo, E. and Hettiarachchy, N. S. (1994). Corn meal sunflower meal extrudates and-their physicochemical properties. J. Food Sci. 59: 432-435.

Spackman, D. H., Stein, E. H. and Moore, S. (1958). Automatic recording apparatus for use in the chromatography of amino acids. Analytical Chem 30: 1190 - 1191.

Umoh, I. B. and Bassir, 0. (1977). Lesser known sources of protein in some Nigerian-peasant diets. Food Chem. 2: 315.

Table 1. Process variable conditions used in the central composite rotatable design

\begin{tabular}{|c|c|c|c|c|c|c|}
\hline \multirow{3}{*}{\multicolumn{2}{|c|}{ Independent process varial }} & \multicolumn{5}{|c|}{ Coded variable levels } \\
\hline & & \multicolumn{2}{|c|}{ Corner points } & \multirow{2}{*}{$\begin{array}{c}\text { Centre point } \\
0 \\
\end{array}$} & \multicolumn{2}{|c|}{ Star points } \\
\hline & & -1.682 & -1 & & +1 & +1.682 \\
\hline Feed composition (\% & xi & 40 & 55 & 70 & 85 & 100 \\
\hline Feed moisture (\%) & $X^{2}$ & 15 & 18 & 21 & 24 & 27 \\
\hline Screw speed (rpm) & $X_{3}$ & 100 & 120 & 140 & 160 & 180 \\
\hline
\end{tabular}


Table 2. Proximate composition of raw materials in the blends

\begin{tabular}{lclc}
\hline Seed composition $(\%)$ & African breadfruit & corn & soybean \\
\hline Protein $(\mathrm{N}$ x 6.25) & $15.76^{\mathrm{a}}$ & $9.62^{\mathrm{b}}$ & $47.28^{\circ}$ \\
Fat & $11.45^{\mathrm{a}}$ & $5.20^{\mathrm{b}}$ & $17.50^{3}$ \\
Ash & $3.00^{\mathrm{a}}$ & $1.50^{\mathrm{a}}$ & $2.50^{\mathrm{a}}$ \\
Crude fibre & $3.00^{\mathrm{a}}$ & $2.60^{\mathrm{a}}$ & $4.00^{\mathrm{a}}$ \\
Carbohydrate & $60.59^{\mathrm{a}}$ & $73.58^{\mathrm{b}}$ & $30.32^{\mathrm{c}}$ \\
Energy (kcal/kg)** & $1715.549^{3}$ & $1594.32^{\mathrm{b}}$ & $1764.84^{\mathrm{c}}$
\end{tabular}

*by difference, **by Atwater factor. Means in the same row with the same superscripts are not significantly $(p>0.05)$ different.

Table 3: Nittrogen solubility index (NSI) of raw and extruded samples at extremes and center point blends

\begin{tabular}{|c|c|c|c|}
\hline \multicolumn{2}{|c|}{ Lower corner point } & Centre point & Higher star point \\
\hline Raw & Extruded & Extruded & Raw Extruded NSI \\
\hline $17.00^{\mathrm{a}}$ & $7.25^{b}$ & $20.00^{c} 7.50^{\mathrm{b}}$ & $22.00^{\mathrm{d}} \quad 9.00^{\mathrm{e}}$ \\
\hline
\end{tabular}


Table 4. Estimated regression coefficients and ANOVA for NSI of extruded blends (a)Regression coefficients

\begin{tabular}{|c|c|c|c|c|}
\hline Source & Coefficient & Standard error & df & p-value \\
\hline \multicolumn{5}{|c|}{ Regression on } \\
\hline Constant & 55.731623 & 36.826502 & & \\
\hline $\mathrm{X} 1$ & -0.645573 & 0.495041 & 1 & 0.2132 \\
\hline $\mathrm{X}_{2}$ & -0.512987 & 2.198949 & 1 & 0.0189 \\
\hline $\mathrm{x}_{3}$ & -0.538983 & 0.266483 & 1 & 0.0627 \\
\hline $\mathrm{Xi} * \mathrm{X}_{1}$ & 0.0006116 & 0.001117 & 1 & 0.5926 \\
\hline $\mathrm{X}] * \mathrm{X}_{2}$ & 0.025668 & 0.020771 & 1 & 0.2369 \\
\hline $\mathrm{Xl} * \mathrm{X}_{3}$ & 0.004028 & 0.003430 & 1 & 0.0599 \\
\hline $\mathrm{X} 2 * \mathrm{X}_{2}$ & -0.052834 & 0.065205 & 1 & 0.4313 \\
\hline$X_{2} * X_{3}$ & 0.019484 & 0.012277 & 1 & 0.0348 \\
\hline$X_{3} * X_{3}$ & 0.000340 & 0.000815 & 1 & 0.6828 \\
\hline $\mathrm{R}^{2}$ & 0.60206 & & & \\
\hline
\end{tabular}

(b.) Analysis of variance (ANOVA)

\begin{tabular}{cccc} 
Factor & df & sum of squares & sig of $\mathbf{~}$ \\
$\mathrm{X} 1$ & 4 & 2.393 & 0.082 \\
$\mathrm{X}_{2}$ & 4 & 9.768 & 0.025 \\
$\mathrm{X} 3$ & 4 & 8.212 & 0.033 \\
\hline
\end{tabular}

$x_{1}=$ feed composition (\%), $x_{2}=$ feed moisture (\%), $x_{3}=$ screw speed (rpm). xi, $x_{2}, x_{3}=$ linear effects, $X i * x i, x_{2} * x_{2}, x_{3} * x_{3}$, = quadratic effects, $x_{1} * x_{2}, x i * x_{3}, x_{2} * x_{3}=$ cross product effects, $N S I=$ nitrogen solubility index. 


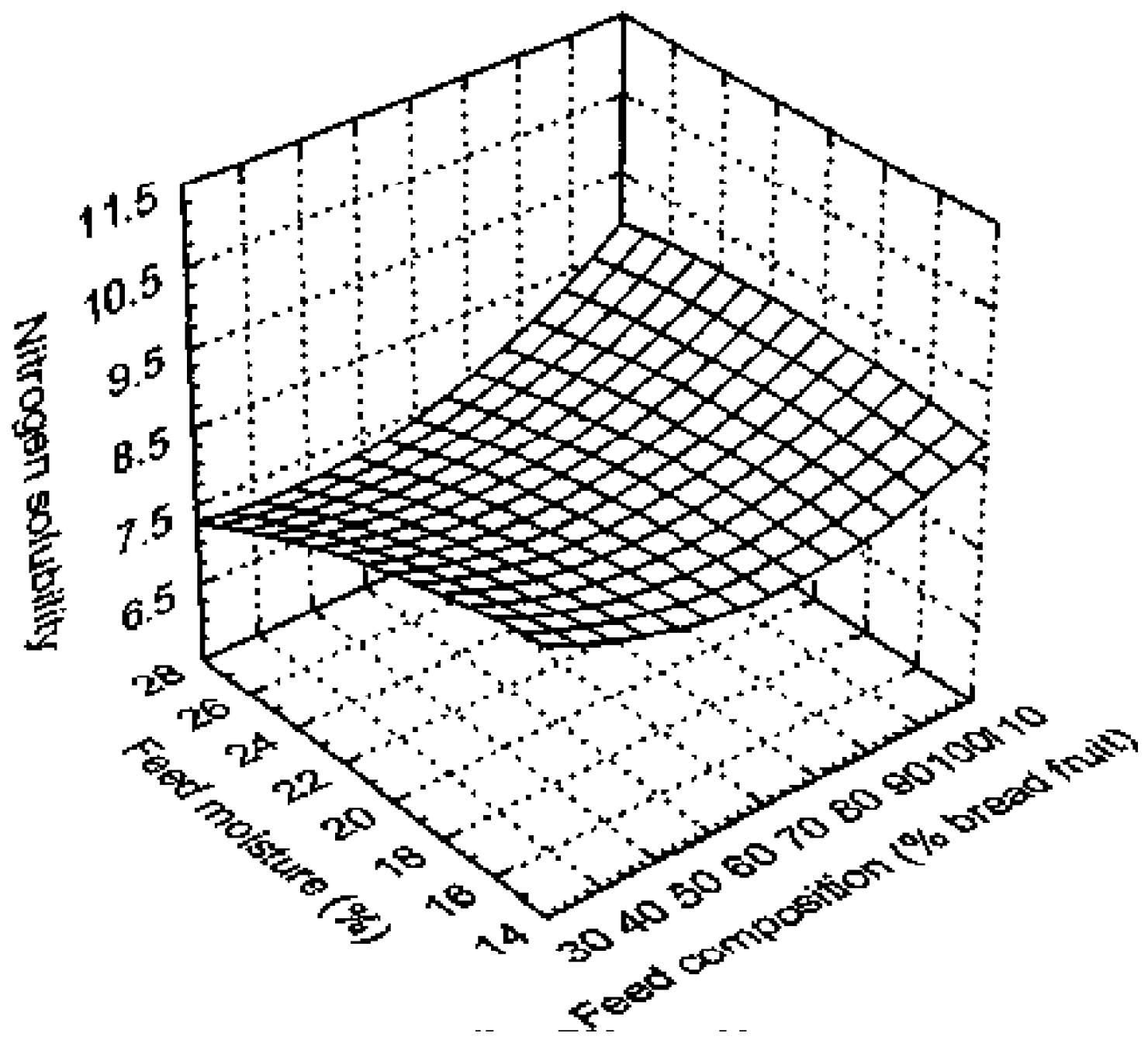

Fig 1. Response surface plot of feed composition (\%) and feed moisture (\%) for extrudate nitrogen solubility index. 


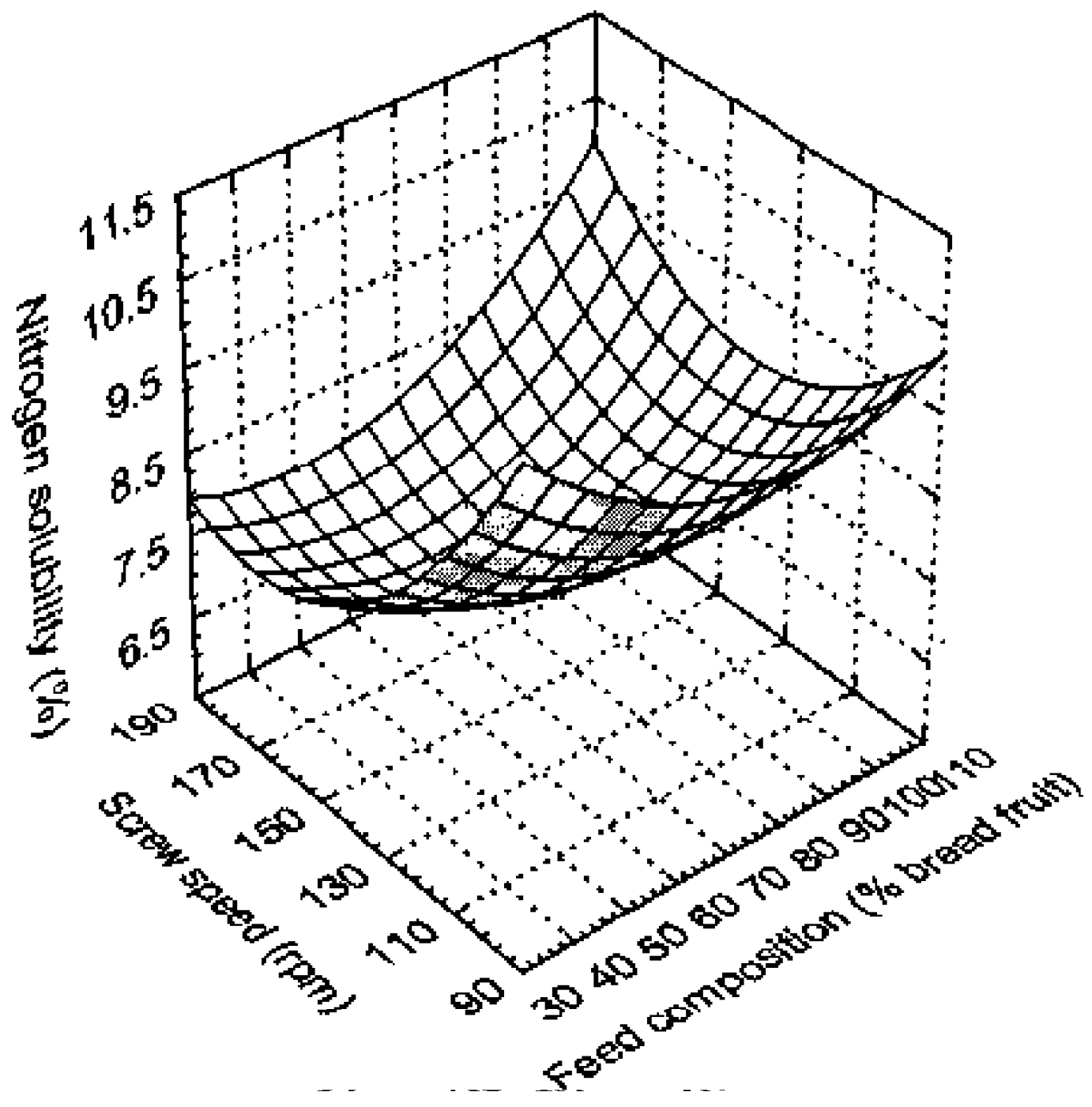

Fig 2. Response surface plot of feed composition (\%) and screw speed (rpm) for extrudate nitrogen solubility index. 
Table 5: Amino acid composition of raw and extruded blends of African breadfruit, corn and defatted soybean at extremes and center points

\begin{tabular}{|c|c|c|c|c|c|c|}
\hline \multirow[t]{2}{*}{$\operatorname{Amino} \operatorname{acid}(g / 16 g N)$} & \multicolumn{2}{|c|}{ Lower corner point } & \multicolumn{2}{|c|}{ Centre point } & \multicolumn{2}{|c|}{ Higher star point } \\
\hline & Raw & Extruded & Raw & Extruded & Raw & Extruded \\
\hline Lysine & 5.04 & 3.22 & 3.01 & 2.00 & 2.64 & 1.80 \\
\hline Histidine & 2.64 & 2.02 & 2.59 & 2.11 & 2.10 & 1.89 \\
\hline Arginine & 5.02 & 4.84 & 4.19 & 4.02 & 3.85 & 3.21 \\
\hline Aspartic acid & 6.17 & 4.82 & 5.20 & 3.88 & 4.22 & 2.10 \\
\hline Threonine & 3.30 & 3.25 & 3.40 & 2.98 & 3.10 & 2.89 \\
\hline Serine & 4.20 & 3.51 & 2.50 & 1.40 & 2.00 & 1.62 \\
\hline Glutamic acid & 10.58 & 10.01 & 9.25 & 8.25 & 9.65 & 7.25 \\
\hline Proline & 2.31 & 2.21 & 2.11 & 1.19 & 1.82 & 1.32 \\
\hline Glycine & 5.11 & 4.14 & 4.00 & 3.94 & 3.85 & 3.31 \\
\hline Alanine & 5.32 & 3.35 & 3.19 & 3.01 & 2.85 & 2.45 \\
\hline Cystine & 2.16 & 1.54 & 1.79 & 1.10 & 1.20 & 1.02 \\
\hline Valine & 3.03 & 2.50 & 2.80 & 2.60 & 2.60 & 2.50 \\
\hline Methionine & 1.53 & 1.35 & 1.30 & 1.02 & 1.40 & 1.22 \\
\hline Isoleucine & 3.23 & 3.20 & 3.00 & 2.10 & 4.10 & 2.25 \\
\hline Leucine & 5.64 & 3.02 & 6.25 & 5.01 & 5.25 & 4.22 \\
\hline Tyrosine & 3.15 & 2.85 & 2.71 & 2.25 & 2.65 & 1.72 \\
\hline Phenylalanine & 4.28 & 4.02 & 3.40 & 3.25 & 3.02 & 2.85 \\
\hline
\end{tabular}

Higher star point blend contains 100, 0 and 0\%; center point blend contains 70, 5 and $25 \%$ while lower (corner point blend contains 40, 5 and 55\% breadfruit, corn and defatted soybean, respectively. 
Table 6: Amino acid percent loss and retention in extruded blends

\begin{tabular}{|c|c|c|c|c|c|c|c|}
\hline \multirow[b]{2}{*}{ Amino Acid $(\%)$} & \multicolumn{2}{|c|}{ Lower corner point } & \multicolumn{2}{|c|}{ Centre point } & \multicolumn{2}{|c|}{ Higher star point } & \\
\hline & Loss & Retention & Loss & Retention & Loss & Retention & \\
\hline Lysine & 36.11 & 63.89 & 33.55 & 66.45 & 31.82 & 68.18 & \\
\hline Histidine & 23.48 & 76.52 & 18.53 & 81.47 & 10.00 & 90.00 & \\
\hline Arginine & 3.59 & 96.41 & 4.06 & 95.94 & 16.62 & 83.38 & \\
\hline Aspartic & 21.88 & 78.12 & 26.10 & 73.90 & 2.61 & 97.39 & \\
\hline \multirow[t]{2}{*}{ Threonine } & 1.52 & 98.48 & 12.35 & 87.65 & 6.77 & 93.23 & \\
\hline & Serine & 40.24 & 59.76 & 44.00 & 56.00 & 19.00 & 81.00 \\
\hline Glutamic acid & 5.39 & 94.61 & 10.81 & 89.19 & 24.87 & 75.13 & \\
\hline Proline & 4.33 & 95.67 & 43.60 & 56.40 & 27.47 & 72.53 & \\
\hline Glycine & 18.98 & 81.02 & 1.50 & 98.50 & 14.03 & 85.97 & \\
\hline Alanine & 37.03 & 62.97 & 5.64 & 94.36 & 14.04 & 85.96 & \\
\hline Cystine & 21.70 & 71.30 & 38.55 & 61.45 & 0.00 & 100.00 & \\
\hline Valine & 17.49 & 82.51 & 7.14 & 92.86 & 3.85 & 96.15 & \\
\hline Methionine & 11.76 & 88.24 & 21.54 & 78.46 & 12.86 & 87.14 & \\
\hline Isoleucine & 0.93 & 99.07 & 33.33 & 66.67 & 45.12 & 54.88 & \\
\hline Leucine & 12.98 & 87.01 & 19.84 & 80.16 & 0.55 & 99.45 & \\
\hline Tyrosine & 10.16 & 89.84 & 16.67 & 83.33 & 35.09 & 64.91 & \\
\hline Phenylalanine & 6.07 & 93.93 & 4.41 & 95.59 & 5.63 & 94.37 & \\
\hline
\end{tabular}

